\begin{tabular}{|l|c|c|c|r|}
\hline $\begin{array}{l}\text { Cuadernos de Investigación Geográfica } \\
\text { Geographical Research Letters }\end{array}$ & 2018 & N $^{\circ} 44(1)$ & pp. 7-13 & $\begin{array}{r}\text { ISSN 0211-6820 } \\
\text { eISSN 1697-9540 }\end{array}$ \\
\hline
\end{tabular}

DOI: http://doi.org/10.18172/cig.3402

(C) Universidad de La Rioja

\title{
THE LITTLE ICE AGE, THE CLIMATIC BACKGROUND OF PRESENT-DAY WARMING IN EUROPE
}

M. OLIVA*

\begin{abstract}
Department of Geography, Faculty of Geography and History, University of Barcelona,
\end{abstract} C/ Montalegre 6, 08001 Barcelona, Spain.

\begin{abstract}
The Little Ice Age (LIA) constitutes the coldest period of the last millennia in Europe. A wide range of natural and historical records show evidence of colder climate conditions between the 14th and 19th centuries, together with a higher frequency of extreme hydroclimatic events. During these centuries, temperatures and precipitations showed different spatio-temporal patterns across Europe. This Special Issue includes eleven scientific works focusing on the climate regime, environmental dynamics as well as socio-economic implications of the LIA in Europe. Besides, this paper also identifies key guidelines for future research on the LIA causes and its consequences on environmental systems in the European continent.
\end{abstract}

\section{La Pequeña Edad del Hielo, precedente del actual calentamiento en Europa}

RESUMEN. La Pequeña Edad de Hielo (PEH) constituye el periodo más frio de los últimos milenios en Europa. Una amplia variedad de registros naturales e históricos atestiguan las condiciones climáticas más frías dominantes entre los siglos XIV y XIX y la mayor frecuencia de eventos hidro-climáticos extremos. Durante estos siglos, las temperaturas y precipitaciones en Europa mostraron diferentes patrones espacio-temporales. En este monográfico se incluyen 11 trabajos centrados en el régimen climático, dinámica ambiental y consecuencias socioeconómicas de la PEH en Europa. Además, el artículo reflexiona sobre las directrices clave de investigación futura sobre las causas de la PEH, así como sus consecuencias ambientales en el continente europeo.

Key words: Little Ice Age, Europe, climate, natural records, historical documents.

Palabras clave: Pequeña Edad de Hielo, Europa, clima, registros naturales, documentos históricos.

* Corresponding author: Marc Oliva, Department of Geography, Faculty of Geography and History, University of Barcelona, Montalegre Street 6, 08001 Barcelona, Spain. E-mail address: oliva_marc@yahoo.com 
Matthes (1940) was the first scientist in using the term Little Ice Age (LIA) to describe the colder climate conditions following the warm Medieval Climate Anomaly (MCA) and before the post-LIA warming recorded during the 20th century. The spatial extent of these cold conditions was mostly observed in the Northern Hemisphere, though a cooling phase has been also reported in other regions with different intensity and time periods (Jones and Mann, 2004; Mann et al., 2009). In Europe, the abundance of natural records and historical sources allowed characterizing with great accuracy the different time periods within the LIA in terms of seasonality and intensity of the cold and moisture conditions (Luterbacher et al., 2004, 2016), together with natural hazards and socio-economic impacts that extreme events triggered in European societies (Pfister and Brázdil, 1999; Wanner et al., 2004).

Despite no clear timing is attributed to the LIA, in Europe it is generally constrained between the 14th and 19th centuries (Matthews and Briffa, 2005), though some studies anticipate it to 1200-1800 AD (Wanner et al., 2011). It is often described as the archetype of cold stage occurred during the present-day interglacial period (Grove, 2004). One of the most visible consequences of the colder conditions was related to the expansion of glaciers, particularly in mid-latitude mountain environments, such as the Alps (Holzhauser et al., 2005; Zumbühl et al., 2008; Nussbaumer and Zumbühl, 2012). This led some scientists to relate the LIA with the prevailing icy climate, with rigorous winters and cool summers favouring glacial advances across Europe. Consequently, the "LIA climate" has been intrinsically linked to the "LIA glacierization" (Matthews and Briffa, 2005), though this concept hides the fact that the LIA climate was characterized not only by a colder regime but also by enhanced climate variability: cold spells, snowstorms, avalanches, droughts, floods, and heat waves (Bradley and Jones, 1992).

A combination of large volcanic eruptions (Hegerl et al., 2007; Luterbacher and Pfister, 2015) and lower solar irradiance (Usoskin et al., 2004) favoured summer cooling in the Northern Hemisphere, which was amplified by feedback processes, such as the increase of sea ice extent in the Arctic (Miller et al., 2012). Temperature decrease initiated at high latitudes subsequently expanded to lower latitudes in Europe (Wanner et al., 2011), with significantly lower temperatures particularly during solar minima, namely the Maunder Minimum (MM, 1645-1715; Luterbacher et al., 2001). Despite the fact that the LIA has been defined as one of the coldest and longer-lasting cold periods during the Holocene (Grove, 2004; Wanner et al., 2011), the temperature decline with respect to present-day annual values was only in the order of $0.5-1{ }^{\circ} \mathrm{C}$ during the coldest stage recorded during the MM (Mann et al., 2009; Luterbacher et al., 2004, 2016). Precipitations also showed different spatio-temporal patterns across Europe, alternating periods with higher and lower moisture regimes (Pauling et al., 2006) and a higher frequency of extreme hydroclimatic events (Brázdil et al., 2010).

Traditional self-sufficient societies were well aware of the significant changing climate conditions prevailing during the LIA as shown by historical documents, paintings, old pictures, etc. Climate was more determinant for those societies than nowadays, strongly conditioning daily life activities. As mentioned before, the LIA 
has not been only used as a reference for cold recent periods during the Holocene (Grove, 2004), but also for comparison with present-day dynamics. This is the recurring case of glaciers, which expanded during the LIA to positions not reached over the last 10,000 years (Bradley and Jones, 1992). The pictures and historical photographs of the glaciers during the late 19th and early 20th century are often compared with present-day pictures of the same areas to make people aware of how climate has changed over the last ca. 150 years (Zumbühl et al., 2008). Generally, the receding and/or disappearance of glaciers during this time period is attributed to the effect of warmer conditions that are (mainly) related to human-induced warming. But we know that the positions reached by the glaciers during these centuries in many mid-latitude mountain environments are close to their maximum during the present-day interglacial (e.g. Central Pyrenees; García-Ruiz et al., 2014). Therefore, these comparisons hide the combined effect of natural and anthropogenic post-LIA warming on terrestrial ecosystem dynamics, not just reflecting the impact of human activities on the climate.

Over the last two decades, there has been an increase in the number of studies combining different data sources, including historical documents and a wide range of multiproxy records, with the purpose of better understanding the spatio-temporal patterns of LIA climate in the European continent (e.g. Luterbacher et al., 2016). Besides, there have been different attempts in certain regions to encompass data from different records and generate high-resolution multiproxy data for specific regions (e.g. Iberia; Oliva et al., in revision). The scientific interest in recent past warm (e.g. MCA, Moreno et al., 2012) and cold periods (e.g. LIA, this issue; Dark Ages, Helama et al., 2017) raises from the need to frame recent climate trends within the natural climate variability. The so-called climate change is often a rapid and widely-used umbrella that gives response to a wide range of processes occurring in Earth systems, some of which forming part of climate variability. In this context, research on climate and environmental systems during the LIA should focus on several key questions such as:

(i) Unveiling the spatio-temporal patterns of the different forcings (volcanic eruptions, solar irradiance, etc.) driving climate variability during the LIA.

(ii) Improving the climate models reproducing with a higher accuracy the coupling between historical climate observations, early instrumental data and multiproxy reconstructions (e.g. tree rings, lake sediments).

(iii) Inferring the frequency and magnitude of extreme events that triggered major hazards in a changing climate scenario such as the LIA, which at the same time can be used nowadays for territorial planning purposes.

(iv) Distinguishing the effects of post-LIA warming in terrestrial ecosystems, particularly from mountain regions, from land-use changes promoted by human activities (e.g. treeline shift due to lower demographic pressure).

With the purpose of examining the effects of the LIA in Europe, this Special Issue encompasses 11 articles dealing with three main issues: 


\section{Climate regime}

Rodrigo et al. (2018) examine climatic conditions in southern Iberia during the LIA and reflect about future challenges to better frame the LIA climate and present-day conditions in the region. Mrgic et al. (2018) analyzes the potential of historical sources in the Balkan region to reconstruct extreme climate conditions and social impacts during the LIA in the area.

\section{Environmental dynamics}

Seven different papers focus on the environmental and cold-climate geomorphological processes prevailing in European mountains during the LIA, as well as its subsequent evolution until nowadays. Hughes (2018) examines the factors controlling glacial dynamics in Mediterranean mountains during the LIA as well as their present-day dynamics. Zumbühl and Nussbaumer (2018) reconstruct the evolution of two glaciers in the Alps using hundreds of historical pictures, providing the world's most accurate reconstructions of glacial advances and retreats for the last centuries. Based on geomorphological evidence, Serrano et al. (2018) discuss about the possible existence of surge glaciers in the Pyrenees during the LIA. FernándezFernández et al. (2018) examine the magnitude of glacial retreat in northern Iceland since the LIA, identifying different phases and associated environmental dynamics. But this Special Issue does not only include contributions focusing on glaciers but also on other cold-climate processes: Kędzia and Kotarba (2018) analyse cryogenic processes existing during the LIA in the Tatra Mountains; Carrera-Gómez and Valcárcel (2018) reconstruct the extent of long-lying snow patches derived from a colder climate in NW Iberian mountains. Gómez-Ortiz et al. (2018) emphasize the value of historical documents for studying the evolution of the Corral del Veleta (Sierra Nevada, Spain) glacier, and Oliveira et al. (2018) examine soil temperatures in the sub-Antarctic environment of Tierra del Fuego.

\section{Socio-economic implications}

García-Hernández et al. (2018, this issue) study a series of large snowstorm events and associate avalanches in the Asturian massif (NW Iberia) as well as their social consequences and natural-human constraints using historical documents. Camenisch et al. (2018, this issue) examine the social and economical impacts of extreme climate events in Switzerland during the early LIA based on a wide range of historical sources accurately preserved in this Alpine country.

In summary, this Special Issue constitutes a compendium of research articles focusing on the climatic conditions prevailing during the LIA in Europe, including the response of terrestrial ecosystems to colder conditions and the impact of extreme climate events in European societies. I am convinced that the quality of the research studies as well as the wide range of topics included in this Special Issue will be a reference for the scientific community interested in similar topics both in Europe and in other continents. 


\section{Acknowledgements}

Marc Oliva is supported by the Ramón y Cajal Program of the Spanish Ministry of Economy and Competitiveness (RYC-2015-17597).

\section{References}

Bradley, R.S., Jones, P.D. 1992. Climate since 1500 A.D. Routeledge, London, 679 pp. http://www. geo.umass.edu/faculty/bradley/bradley1992a.pdf.

Brázdil, R., Demarée, G.R., Deutsch, M., Garnier, E., Kiss, A., Luterbacher, L., Macdonald, N., Rohr, C., Dobrovolný, P., Kolář P., Chromá, K. 2010. European floods during the winter 1783/1784: scenarios of an extreme event during the "Little Ice Age". Theoretical and Applied Climatology 100 (1-2), 163-189. https://doi.org/10.1007/s00704-009-0170-5.

Camenisch, Ch., Rohr, Ch. 2018. When the weather turned bad: Climate impacts on society and economy during the Little Ice Age. An Overview. Cuadernos de Investigación Geográfica 44 (1), 99-114. http://doi.org/10.18172/cig.3395.

Carrera-Gómez, P., Valcárcel, M. 2018. The geomorphological role of snow since the Little Ice Age in the Sierra de Ancares (NW Spain). Cuadernos de Investigación Geográfica 44 (1), 171-185. http://doi.org/10.18172/cig.3379.

Fernández-Fernández, J.M., Andrés, N. 2018. Methodological proposal for the analysis of the evolution of glaciers since the Little Ice Age and its application in the Tröllaskagi Peninsula (Northern Iceland). Cuadernos de Investigación Geográfica 44 (1), 69-97. http://doi. org/10.18172/cig.3392.

García-Hernández, C., Ruiz-Fernández, J., Sánchez-Posada, C., Pereira, S., Oliva, M. 2018. An extreme event between the Little Ice Age and the 20th century: The avalanche cycle of 1888 in the Asturian Massif (Northern Spain). Cuadernos de Investigación Geográfica 44 (1), 187-212. http://doi.org/10.18172/cig.3386.

García-Ruiz, J.M., Palacios, D., Andrés, N., Valero-Garcés, B.L., López-Moreno, J.I., Sanjuán, Y. 2014. Holocene and 'Little Ice Age' glacial activity in the Marboré Cirque, Monte Perdido Massif, Central Spanish Pyrenees. The Holocene 24 (11), 1439-1452. http://doi. org/10.1177/0959683614544053.

Gómez-Ortiz, A., Oliva, M., Salvador-Franch, F., Salvà-Catarineu, M., Plana-Castelví, J.A. 2018. El interés geográfico de los documentos históricos en la explicación del Corral del Veleta (Sierra Nevada, España) durante la Pequeña Edad del Hielo). Cuadernos de Investigación Geográfica 44 (1), 267-292. http://doi.org/10.18172/cig.3415.

Grove, J.M. 2004. Little Ice Ages: Ancient and Modern. Routledge, London (2 volumes).

Hegerl, G.C., Crowley, T.J., Allen, M., Hyde, W.T., Pollack, H.N., Smerdon, J., Zorita, E. 2007. Detection of human influence on a new, validated 1500-year temperature reconstruction. Journal of Climate 20, 650-666. https://doi.org/10.1175/JCLI4011.1.

Helama, S., Jones, P.D., Briffa, K.R. 2017. Dark Ages Cold Period: A literature review and directions for future research. The Holocene. http://doi.org/10.1177/0959683617693898.

Holzhauser, H., Magny, M., Zumbühl, H.J. 2005. Glacier and lake-level variations in westcentral Europe over the last 3500 years. The Holocene 15 (6), 789-801. https:/doi. org/10.1191/0959683605hl853ra.

Hughes, P. 2018. Little Ice Age glaciers and climate in the Mediterranean mountains. A new analysis. Cuadernos de Investigación Geográfica 44 (1), 15-45. http://doi.org/10.18172/ cig.3362.

Jones, P.D., Mann, M.E. 2004. Climate over past millennia. Reviews of Geophysics 42, RG2002. http://doi.org/10.1029/2003RG000143. 
Kędzia, S., Kotarba, A. 2018. The Little Ice Age in the Tatra Mountains. Cuadernos de Investigación Geográfica 44 (1), 47-67. http://doi.org/10.18172/cig.3350.

Luterbacher, J., Pfister, C. 2015. The year without a summer. Nature Geoscience 8, 246-248. http:// doi.org/10.1038/ngeo2404.

Luterbacher, J., Rickli, R., Xoplaki,E., Tinguely, C., Beck, C., Pfister, C., Wanner, H. 2001. The Late Maunder Minimum (1675-1715) - A key period for studying decadal scale climatic change in Europe. Climatic Change 49 (4), 441-462. https://doi.org/10.1023/A:1010667524422.

Luterbacher, J., Dietrich, D., Xoplaki, E., Grosjean, M., Wanner, H. 2004. European seasonal and annual temperature variability, trends and extremes since 1500. Science 303 (5663), 14991503. https://doi.org/10.1126/science.1093877.

Luterbacher, J., Werner, J.P., Smerdon, J.E., Fernández-Donado, L., González-Rouco, J., Barriopedro, D., Ljungqvist, F., Büntgen, U., Zorita, E., Wagner, S., Esper, J., McCarroll, D., Toreti, A., Frank, D., Jungclaus, J., Barriendos, M., Bertolin, C., Bothe, O., Brázdil, R., Camuffo, D., Dobrovolný, P., Gagen, M., García-Bustamante, E., Ge, Q., Gómez-Navarro, J., Guiot, J., Hao, Z., Hegerl, G., Holmgren, K., Klimenko, V., Martín-Chivelet, J., Pfister, C., Roberts, N., Schindler, A., Schurer, A., Solomina, O., von Gunten, L., Wahl, E., Wanner, H., Wetter, O., Xoplaki, E., Yuan, N., Zanchettin, D., Zhang, H., Zerefos, C. 2016. European summer temperatures since Roman times. Environmental Research Letters 11 (2). https:// doi.org/10.1088/1748-9326/11/2/024001.

Mann, M.E., Zhang, Z., Rutherford, S., Bradley, R., Hughes, M.K., Shindell, D., Ammann, C., Faluvegi, G., Ni, F. 2009. Global signatures and dynamical origins of the Little Ice Age and Medieval Climate Anomaly. Science 326 (5957), 1256-1260. https://doi.org/10.1126/ science.1177303.

Matthes,F.E. 1940. Report of the committee on glaciers. Transactions of the American Geophysical Union 1, 396-406. http://glaciers.research.pdx.edu/Report-Committee-Glaciers-1939-40.

Matthews, J.A., Briffa, K.R. 2005. The 'Little ice age': Re-evaluation of an evolving concept. Geografiska Annaler Series A, Physical Geography 87 (1), 17-36. https://www.lakeheadu. ca/sites/default/files/uploads/53/outlines/2014-15/NECU5311/MatthewsBriffa_2005_GA_ LIAconcept.pdf.

Miller, G.H., Geirsdóttir, A., Zhong, Y., Larsen, D.J., Otto-Bliesner, B.L., Holland, M.M., Bailey, D.A., Refsnider, K.A., Lehman, S.J., Southon, J.R., Anderson, Ch., Björnsson, H., Thordarson, T. 2012. Abrupt onset of the Little Ice Age triggered by volcanism and sustained by sea-ice/ocean feedbacks. Geophysical Research Letters 39 (2), L02708. http:// doi.org/10.1029/2011GL050168.

Moreno, A., Pérez, A., Frigola, J., Nieto-Moreno, V., Rodrigo-Gámiz, M., González-Sampériz, P., Martrat, B., González-Sampériz, P., Morellón, M., Martín-Puertas, C., Corella, J.P., Belmonte, A., Sancho, C., Cacho, I., Herrera, G., Canals, M., Grimalt. J.O., JiménezEspejo, F., Martínez-Ruiz, F., Vegas-Villarrúbia, T., Valero-Garcés, B.L. 2012. The Medieval Climate Anomaly in the Iberian Peninsula reconstructed from a compilation of marine and lake records. Quaternary Science Reviews 43, 16-32. https://doi.org/10.1016/j. quascirev.2012.04.007.

Mrgic, J. 2018. Intemperate weather in violent times - Narratives from the Western Balkans during the Little Ice Age (17-18th centuries). Cuadernos de Investigación Geográfica 44 (1), 137-169. http://doi.org/10.18172/cig.3380.

Nussbaumer, S.U., Zumbühl, H.J. 2012. The Little Ice Age history of the Glacier des Bossons (Mont Blanc area, France): a new high-resolution glacier length curve based on historical documents. Climatic Change 111 (2), 301-334. https://doi.org/10.1007/s10584-011-0130-9.

Oliva, M., Ruiz-Fernández, J., Barriendos, M., Benito, G., Cuadrat, J.M., García-Ruiz, J.M., Giralt, S., Gómez-Ortiz, A., Hernández, A., López-Costas, O., López-Moreno, J.I., López-Sáez, J.A., 
Martínez-Cortizas, A., Moreno, A., Prohom, M., Saz, M.A., Serrano, E., Tejedor, E., Trigo, R., Valero-Garcés, B., Vicente-Serrano, S. (2018). The Little Ice Age in Iberian mountains. Earth Science Reviews 177, 175-208. http://doi.org/10.1016/j.earscirev.2017.11.010.

Oliveira, M., Pérez-Alberti, A., Crujeiras, R.M., Rodríguez-Casal, A., Castillo-Rodríguez, F. 2018. A new method for analyzing and representing ground temperature variations in cold environments. The Fuegian Andes, Tierra del Fuego, Argentina. Cuadernos de Investigación Geográfica 44 (1), 293-320. http://doi.org/10.18172/cig.3373.

Pauling, A., Luterbacher, J., Casty, C., Wanner, H. 2006. Five hundred years of gridded highresolution precipitation reconstructions over Europe and the connection to large-scale circulation. Climate Dynamics 26 (4), 387-405. https://doi.org/10.1007/s00382-005-0090-8.

Pfister,C.,Brázdil, R. 1999. Climatic variability in sixteenth-century Europe and its social dimension: a synthesis. Climatic Change 43 (1), 5-53. https://doi.org/10.1023/A:1005585931899.

Rodrigo, F.S. 2018. An overview of the Little Ice Age in Andalusia (Southern Spain): Results and research challenges. Cuadernos de Investigación Geográfica 44 (1), 245-265. http://doi. org/10.18172/cig. 3316 .

Serrano, E., Martín-Moreno, R. 2018. Surge glaciers during the Little Ice Age in the Pyrenees. A controversial dynamics. Cuadernos de Investigación Geográfica 44 (1), 213-244. http://doi. org/10.18172/cig. 3399 .

Usoskin, I.G., Mursula, K., Solanski, S., Schüssler, M., Alanko, K. 2004. Reconstruction of solar activity for the last millennium using 10Be data. Astronomy \& Astrophysics 413 (2), 745-751. https://doi.org/10.1051/0004-6361:20031533.

Wanner, H., Beck, C., Brádzil, R., Casty. C., Deutsch, M., Glaser, R., Jacobeit, J., Luterbacher, J., Pfister, C., Pohl, S., Sturm, K., Werner, P.C., Xoplaki, E. 2004. Dynamic and socio-economic aspects of historical floods in Central Europe. Erdkunde 58 (1), 1-16. http://doi.org/10.3112/ erdkunde.2004.01.01.

Wanner, H., Solomina, O., Grosjean, M., Ritz, S.P., Jetel, M. 2011. Structure and origin of Holocene cold events. Quaternary Science Reviews 30 (21-22), 3109-3123. https://doi.org/10.1016/j. quascirev.2011.07.010.

Zumbühl, H.J., Nussbaumer, S.U. 2018. Little Ice Age glacier history of the Central and Western Alps from pictorial documents. Cuadernos de Investigación Geográfica 44 (1), 115-136. http://doi.org/10.18172/cig.3363.

Zumbühl, H.J., Steiner, D., Nussbaumer, S.U. 2008. 19th century glacier representations and fluctuations in the central and western European Alps: An interdisciplinary approach. Global and Planetary Change 60 (1-2), 42-57. https://doi.org/10.1016/j.gloplacha.2006.08.005. 